\title{
Does Corporate Governance affect Earnings Management? A case study of Deposit Taking Saccos in South Rift Region, Kenya
}

\author{
Josphat Ngeno*, Isaac K. Naibei*, Penina Langat* \\ * Department of Accounting, Finance \& Economics \\ University of Kabianga \\ DOI: 10.29322/IJSRP.11.12.2021.p12046 \\ http://dx.doi.org/10.29322/IJSRP.11.12.2021.p12046
}

\begin{abstract}
Corporate governance practices are aimed at ensuring organization's management provides transparent and accountable leadership. However, many Savings and Credit Cooperative Societies in Kenya are experiencing poor performance. The purpose of this study was to establish the relationship between corporate governance and earnings management of selected deposit taking savings and credit cooperative societies in South Rift region, Kenya. The study was guided by Agency theory, Stakeholders theory and Stewardship theory. The study adopted correlation research design in order to establish the relationship between the dependent and independent variable. The target population for the study was all the 12 deposit taking Savings and Credit Cooperative Societies in the counties of South Rift region. Data was analyzed by the use of descriptive and inferential statistics. Findings from the study demonstrated that board characteristics $(r=0.522, \mathrm{P}<0.05)$ had a moderate significant relationship with earnings management, audit committee $(r=0.859, \mathrm{p}<0.05)$ had a very strong positive correlation with earning management and ownership structure $(r=0.689, p<0.05)$ was second factor which revealed a strong positive significant correlation with earning management of Deposit Taking Saccos in South Rift Region. In general, board characteristics, ownership structure and corporate governance influenced earning management by $70.1 \%\left(R^{2}=0.701 ; p<0.05\right)$. Following the study findings, it was recommended that Deposit Taking Saccos should embrace effective corporate governance taking into consideration of board characteristics, audit committee and ownership structure. The study findings may be significant to Savings and Credit Cooperative Societies as they will acquire a new knowledge on the important aspect of corporate governance which enhances performance.
\end{abstract}

Index Terms- Corporate governance, Deposit Taking Saccos, Kenya

\section{INTRODUCTION}

$\mathrm{T}$ There have been numerous fraud accounting cases in deposit taking savings and credit cooperative societies in developed and developing nations. This rising accounting cases have indicated why firms need to provide reliable, transparent and adhere to accounting ethics in providing information of firms financial performance, (Lang \& Lundholm, 2014). According to Nanda, Leuz and Wysocki (2013), firms are taking measures to safeguard transparency of information, protect auditors' independence and minimize conflict of interest with the purpose of increasing the interests of investors as well as improving on the financial performance of financial and non-financial institutions. According to Emma and Jesus (2013), when there is a poor corporate governance in organizations, leadership of those organizations tend to misuse the resources for their self interest leading to benefit themselves. This leads to decrease or loss of the organization's earnings. Integrity of financial disclosure is an issue of constant concern among accounting practitioners, regulators, and financial analysts; following the aftermath of prominent accounting scandals and frauds involving American firms such as Enron and WorldCom (Prechel, 2020).

An American company, WorldCom, a telecommunications company was discovered to have inflated its assets by almost $\$ 11$ billion, under-reported line costs by way of capitalizing rather than expensing them and highly elevated its revenues figures by making false entries. This was discovered when the company's internal audit department unearthed almost $\$ 3.8$ billion in fraudulent accounts. The company eventually collapsed and these was linked to unethical behaviors of board members from major corporations left many doubting the credibility of auditing as a profession and effectiveness of laid down structures that monitor and assure that corporate boards are performing according to the stakeholders' expectations (Okike, 2007). A study conducted in Indonesia by Dasuki and Lestari (2019) found that practicing good corporate governance improved earnings management and was also associated with best service delivery to the stakeholders of cooperatives in Indonesia. Another study on good corporate governance on performance of cooperatives in Nepal by Puri and Walsh (2018), the findings revealed that when effective corporate governance is in place, it leads to enhanced quality service delivery and thus benefits the cooperate members are empowered economically and socially. This therefore improves earnings management of the cooperatives and leads to the success of those cooperatives. 
In Africa, many scandals involving fraud through financial statement and manipulated earnings has been experienced in many companies for instance Steinhoff Company in South Africa and Cadbury in Nigeria. Steinhoff had recorded fabricated and transactions that were off amounting to 6.5 billion Euros (approximately \$7.4 billion) in the financial years 2009 to 2017, (as summarized in the Steinhoff findings posted on their website). Cadbury had over stated its accounts by 13 billion naira for the period $2003-2006$ (Omoregie \& Ebhodahhe, 2012).

A study by Chinakpude (2019) seeking to determine the relationship between corporate governance and earnings in Nigeria commercial banks. Revealed existence of both positive and negative relationship between corporate governance variables and earning management variables. Earnings per share of Commercial banks in Nigeria were found to influence the size of the board negatively on the other hand ownership structure indicated positive and insignificant relationship with earnings per share. Therefore, this called for banks to monitor and improve board size and ownership structure because of the positive impact they have on the earnings per share.

Hassan, Soliman and Ragab (2020) conducted a study on the impact of Corporate Governance on Earnings Management on firms listed in the Egypt's stock exchange, was meant to determine the nature of relationship between the two variables. The study sought to determine the most effects of corporate governance characteristics on earnings management, to assess the factors that motivated managers to get involved in earning management and then lastly to find out econometric power and importance of different accruals which are based on different models that are meant to determine earnings management in Egypt firms which are listed in the Egypt's stock exchange. In many governments and nongovernmental institutions, fraud on financial reporting has become very rampant.

Kenya has also faced accounting scandals in financial sector such as Trust bank (2006), imperial bank, chase bank and national bank that were accused of manipulating earnings. The DT-SACCOS sub-sector has also been affected with Kitui teachers SACCO fraudulently loosing Ksh. 3 million in the period 2003-2005, Harambee SACCO (2012) where more than Ksh. 350 million was unaccounted for through falsification of records and Bandari SACCO (2015) where Ksh. 5 million was lost through accounting fraud. Such cases involving accounting scandals is clear evidence that artificial Earnings Management (EM) exist. The financial distress situation is attributed to poor management operations because the managers lack good corporate governance (Mwau, 2017).

According to Hassan and Ahmed (2012), corporate governance refers to a technique that is adopted with intentions of lowering cost of agency that comes about due to manager's conflict of interests and shareholders. Conflict of interests emerges simply because the owners of the business are separated from the business itself. This gives room for managers to make decisions that favor their own interests. According to Nordberg, (2020) corporate governance refers to mode of controlling and directing companies. It is primarily the everyday duties and responsibilities that board of management of companies must take up, in order for successful running of those companies as well as their relationship with their stakeholders on the other hand (Pass, 2004). SACCOS are largely governed by a board of directors. It is therefore, the shareholders' responsibility to ensure proper governance is put in place by appointing competent directors and auditors in the SACCOS. Thus, the board oversees the SACCOS by setting strategies, provision of leadership, supervision of the management and stewardship reporting to the shareholders

Good corporate governance discourages managers from carrying out activities that may be deceptive as far as financial reporting is concerned; hence increasing the quality and trustworthiness of financial reporting of companies (Heirany, Sandrabadi \& Mehrjordi, 2013). The board's effectiveness in carrying out its monitoring activities lies on independence, size as well as composition of the board (John \& Senbet, 1998). Some authors believe that the board size should be moderate and meetings should be carried out on a regular basis so as to carry out their monitoring oversight functions (Adebiyi, 2017; Fathi, 2013; Ilmas, Tahir \& Asrar-ui-Haq, 2018). Hence, financial reporting of high quality requires implementation of well-structured corporate governance mechanisms (Nkanbia-Davies, Gberegbe, Ofurum \& Egbe, 2016). The board of directors' impacts on the integrity of financial reporting as their responsibility is the provision of an independent oversight on management and reporting to providers of capital (Khalid \& Arief, 2017). Board structure is an essential tool of monitoring and reducing the managers' opportunistic behaviors. Audit committee compliments corporate governance and is integral to financial reporting in firms which brings about their quality (Hamdan, Al-Hayale \& Aboagela, 2012). Audit committee serves as an integral unit that monitors the accounting choices of firms within the board of directors. When it concerns size and independence of its members as well as skills utilized by the audit entity will impact on how effective their monitoring will be, (Siregar \& Utama, 2008; DeZoort \& Salterio, 2001; Klein, 2002; and Metawee, 2013). Extant literature has identified ownership structure as a useful mechanism which can be a solution in managing the excesses in reporting accounting numbers. The structure is best categorized into two: the share ownership quantifies to insiders and outsiders such as the percentage of institutional as compared to that of individual shareholders (Parveen, Malik, Mahmood, \& Jan 2016).

According to Oso and Semiu (2012), fundamental traits of good corporate governance include honesty, mutual respect and integrity, accountability, trust, complete transparency, performance orientation and responsibility, safeguards of stakeholders' interests and desires, business ethics, openness, values participation, and commitment to organization.

These values provide a convincing assurance that compliance and adherence to them would provide an avenue for the continued business corporations. In addition, these values contribute to the realization of good profits that can be appreciated, corporate goals, and an absolute global market. After careful study, these ingredients were summarized into two; long term relationship and, transactional relationship. Kenyan organizations too have faced several corporate failures that may be attributed to poor structures of corporate governance. A study conducted by Waweru (2018) while studying irregularities of corporate governance on financial markets found out

This publication is licensed under Creative Commons Attribution CC BY.

http://dx.doi.org/10.29322/IJSRP.11.12.2021.p12046

WWW.ijsrp.org 
that, as much as there are best formulated laws, top management find loopholes of embezzling funds for the owners of the business. Further, the research study findings indicated that organizations which were placed on management statutory because they did not manage to achieve financial obligation such as stock brokerage firm and Nyagah stock brokers while Cyton investments, Ekeza Sacco, Chase bank and Imperial closed down their operations. This was because of corporate governance irregularities. Therefore, there is need for corporate in Kenya to come up with good mechanisms that will be adopted for corporate governance thus eliminating or reducing irregularities. EM involves decisions taken during financial reporting and structuring of transactions with an aim of influencing the final financial reports. Lo (2008) in an attempt to clearly distinguish earnings management has classified them into two groups: real earnings management which deals with cash flow and accruals management dealing with changes in accounting policies and estimates. Researchers have gone a step further to understand the effect of earnings management in unexpected accruals so as to determine whether earnings have been managed. This involves establishing the approximations of unexpected growths that are seen as proxy for managers to utilize in accounting discretions (Smaraidos, Thanasas \& Filiou, 2018).

In exploring the impact of corporate governance and its influence on the relationship between quality and earnings management in listed companies in the United Kingdom; Katmon and Al Farooque, (2017) established that there was a negative relationship between earnings management and transparency or disclosure quality for variables influencing earnings management. This implies that the quality of earnings management was influenced by the efficiency of corporate governance mechanism, Dechow, Hutton, Kim and Sloan (2012) in his intent to identify earnings management evaluated the capability of five accrual models with the Jones Model proving most powerful from among firms sampled for overstating earnings. From an exploratory study on the relationship between corporate governance and earnings management by Smaraidos et al., (2018) established that audit quality and quality of accruals had a positive relationship with the practices of corporate governance. The results from the study indicated that firms that had efficient CG practices had higher accruals which had an impact on the quality of financial reporting.

SACCOS have been defined as independent associations formed by people who come together freely and whose intentions are to pursue social, cultural and economic needs as well as aspirations by way enterprises that are democratically managed and which they jointly own (Makori, Munene \& Muturi, 2013; Smaraidos et al., 2018). Further Saccos are explained as financial institutions that are user owned and provide savings and credit services as well as a number of financial services to members (WOCCU, 2005). Saccos are autonomous associations of individuals who come together and get united voluntarily with a common goal of meeting social and economic needs. The Saccos are democratically controlled and operate under cooperatives principles. The Saccos are guided by values which are equity, honesty, accountability, efficiency, transparency, democracy, openness, mutual caring, quality and social responsibility (Kabaiku, 2018).

Over time there has been consistent and swift development of the SACCOs calling for the enactment of the SACCO Society Act of 2008. This legislation empowers SACCOs and Societies Regulatory Authority (SASRA) to license, regulate and supervise all SACCOs taking deposit by adopting both prudential as well as non-prudential regime (SASRA, 2010). The government through this regime intended to improve financial access and affordability to many people to strengthen financial muscle of these SACCOs and enhance their efficiency. Time on, SACCOs have progressed and started other services such as specialized banking services, providing saving options, debit card businesses as well as the transfer of cash across various platforms as reported in Processor (2012). In Kenya the Sacco sub sector has been put under the regulation of two institutions namely; the office of the Commissioner for Co-operatives and SASRA each with unique supervisory roles to play. The commissioner for cooperatives supervises non-Deposit Taking Saccos which operate back-office services whereas SASRA licenses and regulates Deposit Taking Saccos (Ngeno, 2019). The Cooperative Societies Act CAP 490 bestows upon SASRA the powers to licence the Saccos that have been fully registered. The non-deposit taking segment comprises Sacco societies whose business is primarily concerned with mobilization of deposits which is then lent to members (Sacco Supervision Annual Report, 2016). There were 176 SACCOs granted licenses to provide deposit taking services in the country at the commencement of the year 2018, although two of the SACCOs had their respective deposit-taking licenses revoked during the year leaving 174 SACCOs. Anisa and Hapsoro (2017) indicated that firm size can also be determined by the sales growth of a firm. This is the ratio indicating company's ability in maintaining its position economically amidst growth of the economy and firm's tendency to make high profits and thus help in attracting potential investors who will invest their financial resources in the firm. According to the study, it was revealed there existed a positive significant effect on earning management. Organizations are monitoring and evaluating the, number of employed workers, sales growth, for how long they have been in operational and their profit growth among other indicators in order to determine their institutions size. Despite the changes in the indictors business models are subjected to differences in uniqueness that is exhibited between large organizations and small organizations (Petruzzelli, Ardito \& Savino 2018). According to Hörisch, Johnson and Schaltegger (2015) asserts that earning management may be influenced by the organization's size. Firm size has been found to have both positive and negative influence on earnings management. This is according to Bourlakis, Maglaras, Aktas, Gallear, and Fotopoulos (2014) asserted that firm's size may influence earning management through sales growth, age of the firm, capital intensity and number of employees in the firm. When the firm post rapid growth of sales, having financial and non financial resources available contributes to positive influence on earning management. A firm with high sales growth and enjoying high capital intensity indicates how big the firm is.

Agency theory creates a basis which the owner of business can keep monitoring manager's performance in order to ascertain whether they are using the business resources and their personal expertise or competence in attaining good results that appeals the principal. This calls for board of directors to monitor management for right financial reporting and reliability. Sometimes false financial information is

This publication is licensed under Creative Commons Attribution CC BY

http://dx.doi.org/10.29322/IJSRP.11.12.2021.p12046

WWW.ijsrp.org 
provided by earnings and management and this calls for firm's internal monitoring mechanism. For the true picture of firm's performance information, there is need to have internal board of directors who are governed by corporate governance (Dibia \& Onwuchekwa, 2014).

There are various studies which have been done on corporate governance and earnings management. Ali, Butt, and Hassan (2016) sought to find out on the effect of corporate governance and earnings management on companies listed in stock exchange in Pakistan. From their findings, it was concluded that there was no relationship between corporate governance and earning management. This was contrary and unconventional from other studies that have established a positive relationship between governance practices and earnings management. A study conducted in Nigeria by Dibia et al., (2014) on corporate governance appraisal on earning management of financial institutions in Abuja city established that board size and firm size are associated with earnings management. While board independence, audit committee independence, audit type and CEO shares were not associated to earnings management. The association between board size and earnings management was seen to be negative. This implied that having a larger board size with more of none executive members could reduce the level of earnings management in Nigeria. Their findings contradicted with the findings of the study conducted in Pakistan by Ali et al., (2016). Further, another study was carried by Muchoki (2013) sought to determine the impact of corporate governance techniques and Nairobi Stock Exchange quoted companies earnings management. The findings indicated CEO duality was significant to earning management. Further, findings showed that, there existed negative significance relationship between board independence and earning management.

Corporate governance system is expected to play a key role in ensuring that organization management provides transparency and accountability by reporting financial statements which are free from accounting fraud and errors. In Kenya, SASRA introduced corporate governance in Saccos to provide a framework for boosting trust and confidence of investors and stakeholders. Deposit taking SACCOs plays a critical role in the economy by mobilizing savings and they provide important services more especially to low-income earners who make up large number of populations in Kenya. Well managed Saccos can contribute to better and improved firm performance. However, Saccos in Kenya continue to face poor performance which has culminated in closure to some of them. Some of the Saccos have been put under receivership, liquidation or deregistered because of conspiracy to defraud and failing to submit the Saccos' audited accounts to SASRA and cases of different account of theft by management or board of the Sacco. It is not clear whether corporate governance parameters can be used to enhance earnings management in Saccos. Studies have been conducted both internationally and locally on the effects of corporate governance on EM and the studies have posted mixed findings on the relationship between the research variables. In Kenya, the studies have majorly focused on manufacturing firms, commercial banks and listed companies in Nairobi securities thus there is limited research on deposit taking Saccos in Kenya. Therefore, the purpose of this study was to determine the relationship between corporate governance and earning management of deposit taking savings and credit cooperative societies in South Rift region, Kenya. The overall objective of the study was to establish the relationship between corporate governance and earnings management of selected deposit taking SACCOS in South Rift region, Kenya.

\section{IDENTIFY, RESEARCH AND COLLECT IDEA}

It's The study adopted correlation survey research design. The design assists the researcher to determine the strength and direction of the relationship existing between independent and dependent variables. According to Orodho (2012), this type of design is important because it enables the researcher to establish the relationship that exists between independent variables and the dependent variable, which is the relationship between corporate governance and earnings management. Target population of this study included all the 12 DT-SACCOs registered under Sacco Societies Regulatory Authority (SASRA) in Bomet, Kericho and Narok Counties from 2015 to 2019. The 12 Saccos were selected because they have more than 10 employees. Those with less than 10 were not considered. The study targeted respondents from all deposit-taking SACCOs in South Rift region which include Chief Executive Officers, board members, internal auditor and accountant. Because of the experience of respondents targeted and accuracy of data to be collected the respondents were purposively picked. The study adopted census sampling method where all the 148 officers (Chief Executive Officers, board members, internal auditor and accountant) of DT Saccos in all the three counties in South Rift region were selected to form the sample size. Kothari (2004) asserts that in a case where all members of the target population are taken into consideration, the population becomes representation. This fulfilled the requirement of reliability, representation, efficiency among other factors.

Data was collected through the use of questionnaires which were self-administered on the selected respondents to obtain primary data. The researcher obtained secondary data by use of abstraction method from secondary data sources that comprise of statements of corporate governance as well as financial statements from 12 deposit taking savings and credit cooperative societies as published by SASSRA. Secondary data collected from secondary sources such as published findings of DT-SACCOS include: number of directors, audit committee size, composition, and experience, major shareholders' composition, issue of having executive or non-executive board members, the issue of the CEO having dual responsibilities as well as financial data with debt amounts and a host of other financial disclosures.

Validity is important in determining whether a measurement tool adopted reliable measures that could measure what it purports to measure. These elements are important where the objectives of the entire study are to be achieved (Creswell, 2009). According to Mohajan (2017), validity is the appropriateness, importance and meaningful of the instruments to yield results that are reliable. To assess validity of the instrument, content validity and construct validity of the instrument were examined. For content validity, the research instrument was checked by experts for the purpose of ensuring that the research instrument measured what it was supposed to measure

This publication is licensed under Creative Commons Attribution CC BY.

http://dx.doi.org/10.29322/IJSRP.11.12.2021.p12046

www.ijsrp.org 
in relation specific indicators used. On the other hand, construct validity was enhanced by dividing the questionnaire into different sections in order to ensure each part assessed specific information for a particular objective and ensure the same information is in correlation with the conceptual framework. Reliability deals with the extent to which a chosen method of measuring gives consistent results when the procedure is done repeatedly (Orodho, 2012). To ensure reliability of the instrument, piloting was carried out on Saccos in the same region that were not used in the final study. This helped to ensure that the target population for the study was not interfered with. Cronbach's Alpha coefficient was used to measure reliability of which an alpha coefficient of 0.8161 was obtained. According to Mugenda and Mugenda an Alpha coefficient of 0.7 and above is considered ideal for a study of this nature. Quantitative data analysis was done through descriptive statistics, inferential statistics, measure of central tendency, and measure of dispersion. Multiple regression analysis was carried out to determine relationship between independent and dependent variables in conformity with the prescription by a host of scholars (Faraway, 2002; Cohen, Cohen, Stephen, West, Leona \&Aiken, 2003). Multiple regression analysis was preferred because it has ability to establish the existence of a relationship (positive or negative) between independent and dependent variables (Castillo, 2009). the foremost preliminary step for proceeding with any research work writing.

\section{FINDINGS AND DISCUSSIONS}

The findings on demographic distribution of the respondents indicates that the sample was fairly distributed in terms of gender, experience, and age. The findings revealed that the age of the respondents was distributed between 25 years and above 56 years. Majority of the respondents $66(52.8 \%)$ were between the age categories of 36 and 45 years. This was followed by those between 26 and 35 Years $36(28.8 \%)$. Those who had worked between below 25 years were $7(5.6 \%)$ and 16(12.8) had worked for 46 years and above in the selected deposit taking Saccos. Regarding the duration that the respondent had worked at the particular deposit taking Sacco, majority $67(53.6 \%)$ of the employees had worked for the Sacco for a period of between 6 and 15 years. 6(4.8\%) had worked for less than 1 year while $34(27.2 \%)$ had worked for a period of between 1 and 5 years and 18(14.4\%) had worked for more than 15 years. These findings imply that majority of the employees had fairly stayed at the deposit taking Sacco and therefore had a fair understanding of operations within the Sacco.

The first objective of the study was to assess the relationship between the dependent variable (earning management) and the predators (corporate governance). To achieve this objective, the study carried out correlation analysis, Analysis of variance and regression analysis. Correlation analysis was carried out to assess the strength of linear relationship between the corporate governance and earnings management.

Table 1: Correlation analysis

$\begin{array}{cccc}\text { Board } & \text { Audit } & \text { Ownership } & \text { Earnings } \\ \text { Composition } & \text { Committee } & \text { Structure } & \text { Management }\end{array}$

\begin{tabular}{lccc}
\hline Board Composition & 1 & & \\
Audit Committee & 0.026 & 1 & 1 \\
Ownership Structure & 0.055 & $0.344^{* *}$ & $0.489^{* *}$ \\
Earnings Management & $0.222^{*}$ & $0.259^{* *}$ & 1 \\
$N=125$ & & & \\
$* *$ Correlation is significant at $0.01 ; *$ correlation is significant at 0.05 sig \\
\hline
\end{tabular}

Source: Field Data, (2021)

The findings from Table 1 demonstrates that board characteristics had a moderate significant relationship with earnings management of selected deposit taking SACCOS ( $\mathrm{r}=0.522$, $\mathrm{p}<0.05)$. The findings did not concur with the findings of Rashid (2018) which indicted a positive significant relationship with earning management while the current study indicated moderate significant relationship. The study adopted secondary data and focused on firms listed in Dhaka Stock Exchange. Audit committee had a strong positive correlation with and earnings management of selected deposit taking SACCOS $(r=0.859, \mathrm{p}<0.05)$. The findings contradict with the findings of Fodio, Ibikunle and Oba (2013) which found out a negative relationship between audit committee and earning management. Ownership structure indicate strong positive significant correlation with earnings management of selected deposit taking SACCOS ( $\mathrm{r}=0.689$, $\mathrm{p}<0.05)$. These findings are similar to the findings of Latif and Abdullah (2015) despite the findings not indicating a strong relationship as the current study.

The regression model was adopted to test hypothesis of this study with significant of $5 \%$. This has been summarized in the Table 2

Table 2 Summary of Regression Model

\begin{tabular}{lllllll}
\hline Model & $\mathrm{R}$ & R Square & $\begin{array}{l}\text { Adjusted } \\
\text { Square }\end{array}$ & $\begin{array}{l}\text { R } \\
\text { Std. Error of the } \\
\text { Estimate }\end{array}$ & Durbin-Watson \\
\hline 1 & $0.837^{\mathrm{a}}$ & 0.701 & 0.671 & 0.66117 & 2.074 \\
\hline
\end{tabular}

This publication is licensed under Creative Commons Attribution CC BY.

http://dx.doi.org/10.29322/IJSRP.11.12.2021.p12046

WWW.ijsrp.org 
a. Predictors: (Constant), Board Structure, Audit Committee and Ownership Structure

b. Dependent Variable: Earnings Management

Source: Field Data, (2021)

The result in Table 2 shows that there exist a strong relationship between corporate governance and earning management of deposit taking Saccos. This has been due to Board Structure, Audit Committee and Ownership Structure which contributes to about $70.1 \%$ of variation in earning management of deposit taking Saccos while the remaining $29.9 \%$ is contributed by other factors $(\mathrm{R}$ square $=0.701)$. Study findings by Cornett, McNutt and Tehranian, (2009) concurred with these findings, indicating corporate governance established a positive relationship on earning management.

Table 3 Regression Coefficient

\begin{tabular}{llllll}
\hline Model & \multicolumn{2}{l}{$\begin{array}{l}\text { Unstandardized } \\
\text { Coefficients }\end{array}$} & $\begin{array}{l}\text { Std'zd } \\
\text { Coeff' } \\
\text { B }\end{array}$ & T & Sig. \\
\cline { 2 - 5 } & $\mathbf{B}$ & $\begin{array}{l}\text { Std. } \\
\text { Error }\end{array}$ & & \\
\hline (Constant) & 1.995 & 0.513 & & 3.888 & 0.000 \\
Board Structure & 0.504 & 0.078 & 0.500 & 6.461 & 0.001 \\
Audit Committee & 0.744 & 0.104 & 0.714 & 7.154 & 0.000 \\
Ownership Structure & 0.589 & 0.091 & 0.538 & 6.473 & 0.000 \\
a. Dependent Variable: Earnings Management & & & \\
\hline
\end{tabular}

Source: Field Data, (2021)

Results in Table 3 it is revealed that board structure, audit committee and ownership structure had positive relationship with earning management of deposit taking-Saccos in South Rift Region $(\mathrm{P}<0.05)$. In detail, the effect of board structure on earning management is statistically significant at $5 \%$ of significance $(\mathrm{t}=6.461, \mathrm{P}<0.05)$. This result indicated that $\beta=0.504$ which implies that a unit increase in board structure increases a unit increase in earning management of Deposit Taking Saccos in South Rift Region. The effect of audit committee on earning management is statistically significant at $5 \%$ of significance $(\mathrm{t}=7.154, \mathrm{P}<0.05)$. The output shows that $\beta=0.744$ implying that a unit increases in audit committee increases earning management earning management of Deposit Taking Saccos in South Rift Region. The effect of ownership structure on earning management is statistically significant at 5\% of significance ( $\mathrm{t}=6.473$, $\mathrm{P}<0.05)$. This signifies $\beta=0.589$ meaning a unit increase in ownership structure increases earning management of Deposit Taking Saccos in South Rift Region.

\section{SUMMARY, CONCLUSIONS AND RECOMMENDATIONS}

The study findings on relationship between ownership structure and earning management indicated several observations. First, the result indicated that managerial ownership greatly played a great role in earning management in Deposit Taking Saccos. The findings also indicate that ownership concentration is an important factor in enhancing earning management in Saccos. Similarly, the findings indicate that institutional ownership supports Deposit Taking Saccos and this enhances their earning management. in overall, ownership structure strongly helps saccos in enhancing their earning management. The findings indicated that predictions on the relationship between audit committee and earning management in Deposit Taking Saccos in South Rift Region showed strong positive and statistically significant. According to these findings, it can be concluded that audit committee is the second important factor affecting earning management of Deposit Taking Saccos and hence very important element in Saccos earning management.

Regression model was used to test whether ownership structure significantly predicted earning management in Deposit Taking Saccos. In relation to the study findings, the study recommends that Saccos need to enhance their board characteristics in terms of the size of the board, board composition and look at the duality of the chief executive officer. This will foster effective decision in the Saccos. Therefore, the study recommends that Saccos need to have a small number of board members. This will help in improving quality of board actions and Saccos earning management. Also it is recommended that board must be composed with people who have different skills, experiences, gender and age. This will enhance deep and rich discussions hence bring appropriate expertise to challenges facing Saccos. On the basis of the study findings, the study recommends that there is a need to separate the board chairperson from the position of CEO. This will help in enhancing transparency. This is the highest variable that affected earning management in Saccos with strong and positive significant. For better earning management in Saccos, the study recommends the audit committee in Saccos to have experience and a knowhow on corporate governance as key factors to be considered when selecting audit committee team. This will bring expertise and in depth knowledge in the auditing of the Saccos. The study also recommends that the audit committee should not be interfered with when conducting their functions. This will give the audit committee freedom in conducting their mandate freely and fairly hence accountability and transparency is enhanced in the reports.

According to the study findings, ownership structure was the second highest factor that contributes to earning management in Saccos. Therefore, the study recommends the Saccos to encourage managerial ownership, ownership concentration and institutional ownership. 
This is because they have a strong positive influence on the quality which is associated with the performance o the Saccos hence improving earning management positively.

The study suggest that similar study can carried on the relationship between corporate governance and earning management on NonDeposit Taking SACCOs. This will assist in identifying whether the observed findings Saccos earning management will be the same. On the same note, the same study can be conducted but in different countries in order to ascertain whether the findings illustrated in the South Rift counties are replicable in other counties

The preferred spelling of the word "acknowledgment" in American English is without an "e" after the "g." Use the singular heading even if you have many acknowledgments.

\section{REFERENCES}

1) Abri, A. F., Arumugam, D., \& Balasingam, S. (2019). Impact of the corporate governance on the financial statement fraud: a study focused on companies in Tanzania. International Journal of Recent Technology and Engineering, 7(5), 336-341.

2) Adebiyi, W. K. (2017). Board composition and financial reporting quality of deposit money banks in Nigeria. International Journal of Innovative Finance and Economic Research, 5(4), 97-104.

3) An, Z., Li, D., \& Yu, J. (2016). Earnings management, capital structure, and the role of institutional environments. Journal of Banking \& Finance, 68, 131152.

4) Andries, P., \& Stephan, U. (2019). Environmental innovation and firm performance: How firm size and motives matter. Sustainability, 11(13), 35-85.

5) Bourlakis, M., Maglaras, G., Aktas, E., Gallear, D., \& Fotopoulos, C. (2014). Firm size and sustainable performance in food supply chains: Insights from Greek SMEs. International Journal of Production Economics, 152, 112-130.

6) Chinakpude, I. E. (2019). Effect of Corporate Governance on Earnings Management of Commercial Banks in Nigeria. International Journal of Accounting, Finance and Risk Management, 4(2), 61-87.

7) Cohen, J., Cohen, P., Stephen, G., West, and Leona S. Aiken (2003). Applied multiple regression/correlation analysis for the behavioral sciences, 3.

8) Cornett, M. M., McNutt, J. J., \& Tehranian, H. (2009). Corporate governance and earnings management at large US bank holding companies. Journal of Corporate finance, 15(4), 412-430.

9) Creswell, J. W., \& Zhang, W. (2009). The application of mixed methods designs to trauma research. Journal of Traumatic Stress: Official Publication of The International Society for Traumatic Stress Studies, 22(6), 612-621.

10) Dasuki, R. E., \& Lestari, A. (2019). Implementation of Good Corporate Governance to the Value of Cooperative Company. Journal of Economic Empowerment Strategy (JEES), 2(1), 24-41.

11) Davis, J. H., Schoorman, F. D. \& Donaldson, L. (1997). Toward a Stewardship Theory of Management. Academy of Management Review, $22,20-47$.

12) Dechow, M., Hutton, P., Kim, H. and Sloan, G. (2012). Detecting earnings management: A new approach. Journal of Accounting Research, 50(2), $275-334$.

13) DeZoort, F. T. \& Salterio, S. E. (2001), The effects of corporate governance experience and financial reporting and audit knowledge on audit committee directors' judgments, Auditing: A Journal of Practice \& Theory 20,31-48.

14) Dibia, N. O., \& Onwuchekwa, J. C. (2014). An appraisal of corporate governance mechanisms and earnings management in Nigeria. International Journal of Finance and Accounting, 3(2), 49-59.

15) Emma, G.M. \& Jesus, S.G. (2013). Does Corporate Governance Influence Earnings Management in Latin American Markets? Journal of Business Ethics, 10(6) 851-892.

16) Essel, B. K. C., Adams, F., \& Amankwah, K. (2019). Effect of entrepreneur, firm, and institutional characteristics on small-scale firm performance in Ghana. Journal of Global Entrepreneurship Research, 9(1), 1-20.

17) Faraway, J. J. (2002). Practical regression and ANOVA using $R$ (Vol. 168). Bath: University of Bath.

18) Fathi, J. (2013). Corporate governance system and quality of financial information. Mediterranean Journal of Social Sciences, 4(2),129-142

19) Fodio, M. I., Ibikunle, J., \& Oba, V. C. (2013). Corporate governance mechanisms and reported earnings quality in listed Nigerian insurance firms. International Journal of Finance and Accounting, 2(5), 279-286.

20) Gall, M. D., Gall, J. P., \& Borg, W. R. (2007). Collecting research data with questionnaires and interviews. Educational research: An introduction, 12(10), $227-261$

21) Gorganli, J., \& Vakilifard, H. (2014). The effect of firm size and growth opportunity on accounting discretion and its relationship with future stock return (management opportunism test). European Online Journal of Natural and Social Sciences, 3(3), pp-511.

22) Hamdan, A. M. M., Al-Hayale, T. H.,\& Aboagela, E. M. (2012). The impact of audit committee characteristics on accounting conservatism: Evidence from Jordan.Australasian Accounting Business \& Finance Journal, 7(4), 51.

23) Hassan, A. E., Soliman, M. M., \& Ragab, A. A. (2020). The Effects of Corporate Governance Mechanisms on Earnings Management in Egyptian listed firms in the Stock Market. International Journal of Scientific and Engineering Research 4(11):1609.

24) Heirany, F., Sandrabadi, A. N.,\& Mehrjordi, F. F. (2013). Investigating the effects of corporate governance mechanisms on the quality of accounting profit. International Journal of Academic Research in Accounting, Finance and Management Studies, 3(3), 315-328.

25) Hörisch, J., Johnson, M. P., \& Schaltegger, S. (2015). Implementation of sustainability management and company size: A knowledge-based view. Business Strategy and the Environment, 24(8), 765-779.

26) Ilmas, F., Tahir, S., \& Asrar-ul-Haq, M. (2018). Ownership structure and debt structure as determinants of discretionary accruals: An empirical study of Pakistan. Cogent Economics \& Finance, 6(1), 1-27.

27) John, K.,\& Senbet, L. W. (1998). Corporate governance and board effectiveness. Journal of Banking and Finance, 22(1), 371-403.

28) Kabaiku, P. M. (2018). Savings and Credit Cooperative Societies (SACCOs) in Kenya. Jumuga Journal of Education, Oral Studies, and Human Sciences (JJEOSHS), 1(1).

29) Katmon, N., \& Al Farooque, O. (2017). Exploring the impact of internal corporate governance on the relation between disclosure quality and earnings management in the UK listed companies. Journal of Business Ethics, 142(2), 345-367.

30) Khalid, M.,\& Arief, S. (2017). Managerial ownership, corporate governance and earnings quality: The role of institutional ownership as moderating variable Pertanika Journal of Social Sciences and Humanities, 25(S), 241-254.

31) Klein, A. (2002), "Audit committee, board of director characteristics and earnings statement", Journal of Accounting \& Economics 33, 375-400.

32) Lang, M. \& Lundholm, R. (2014). Voluntary Disclosure and Equity Offerings: Reducing Information Asymmetry or Hyping the Stock. Contemporary Accounting Research, 17(4), 623-669.

33) Latif, S. and Abdullah, F. (2015). The effectiveness of corporate governance in constraining EM in Pakistan. The Lahore Journal of Economics, 20(1), 135155 .

34) Lo, K. (2008). Earnings management and earnings quality. Journal of accounting and economics, 45(2-3), 350-357. 
35) Makori, J., Munene, C., \& Muturi, W. (2013). The challenges Facing Deposit-taking SACCOs' Regulatory Compliance in Kenya: A Case of the Gusii Region. International Journal of Contemporary Research in Business, 4(2), 1015-1015.

36) Metawee, A. (2013). The relationship between characteristics of audit committee, board of directors and level of earning management, Evidence from Egypt. Journal of International Business and Finance, 6(1), 1-34.

37) Mohajan, H. K. (2017). Two criteria for good measurements in research: Validity and reliability. Annals of Spiru Haret University. Economic Series, 17(4), 59-82.

38) Muchoki, G. W. (2013). The relationship between corporate governance practices and earnings management for companies quoted at the Nairobi Securities Exchange (Doctoral dissertation, University of Nairobi).

39) Mwau, J. M. (2017). Relationship Between Audit Tenure and Earnings Management of Deposit Taking Sacco's in Nairobi County (Doctoral dissertation, University of Nairobi).

40) Mwita, R. M., Chachage, B., Mashenene, R. G., \& Msese, L. R. (2019). The Role of Financial Accounting Information Transparency in Combating Corruption in Tanzanian SACCOS. African Journal of Applied Research (AJAR), 5(1), 108-119.

41) Nanda, D., Leuz, C. \& Wysocki, P. D. (2013). Earnings Management and Investor Protection: An International Comparison. Journal of financial economics, 69(3), 505-527.

42) Ngeno, J. C. (2019). Capital adequacy framework, funds allocation strategy and financial performance of deposit taking Sacco's in Kenya (Doctoral dissertation, KeMU).

43) Nkanbia- Davis, L. O., Gberegbe, F. B., Ofurum, C. O.,\& Egbe, S. (2016). Corporate governance and earnings quality of listed banks in Rivers state. International Journal of Business and Management Invention, 5(7), 29-33.

44) Nordberg, D. (2020). The Cadbury Code and Recurrent Crisis: A Model for Corporate Governance? Springer Nature.

45) Okelo, O. M. (2014). Sustainable competitive advantage among savings and credit co-operative societies in Nairobi County (Doctoral dissertation, University of Nairobi).

46) Okike, E. N. (2007). Corporate governance in Nigeria: The status quo. Corporate Governance: An International Review, 15(2), $173-193$.

47) Omoregie, N., \& Ebhodaghe, L. E. (2012). The Effects of Accounting Scandals on Public Confidence in Financial Reports: International Journal of Governance and Development,1(2), 92-97

48) Orodho, A. J. (2012). Techniques of Writing Research proposals in Education and Social Sciences. Kenya: Kanezja Publishers.

49) Oso, L., \& Semiu, B. (2012). The concept and practice of corporate governance in Nigeria: The need For public relations and effective corporate communication. Journal of Communication, 3(1), 1-16.

50) Pass, C. (2004). Corporate governance and the role of non-executive directors in large UK companies: an empirical study. Corporate Governance: The international journal of business in society, 7(2), 141-164.

51) Petruzzelli, A. M., Ardito, L., \& Savino, T. (2018). Maturity of knowledge inputs and innovation value: The moderating effect of firm age and size. Journal of Business Research, 86, 190-201.

52) Prechel, H. (2020). Normalized Financial Wrongdoing: How Re-regulating Markets Created Risks and Fostered Inequality. Stanford University Press.

53) Puri, D. L., \& Walsh, J. (2018). Impact of Good Governance on Performance of Cooperatives in Nepal. Management \& Marketing, 16(2), 209-224.

54) Rashid, A. (2018). Board independence and firm performance: Evidence from Bangladesh. Future Business Journal, 4(1), 34-49.

55) SACCO Societies Regulatory Authority (SASRA). (2016). SACCO Supervision Annual Report, 2016 (Deposit-Taking SACCOs). Nairobi: SASRA.

56) SASRA (2019). The Sacco Societies Regulatory Authority (SASRA). Supervision Report. Nairobi, Kenya.

57) Siregar, S. and Utama, S. (2008). Type of EM and the effect of ownership structure, firm size, and corporategovernance practices: Evidence from Indonesia, The International Journal of Accounting 43(1), 1-27.

58) Smaraidos, V., Thanasas, G. L., \& Filiou, A. (2018). The impact of corporate governance on earnings management in emerging economies: the Greek evidence. International Journal of Comparative Management, 1(3), 317-330.

59) Waweru, N. (2018). Audit committee characteristics, board ethnic diversity and earnings management: evidence from Kenya and Tanzania. International Journal of

60) WOCCU (World Council of Credit Unions) (2005). Statistics Report. Retrieved fromwww.woccu.org.

\section{AUTHORS}

First Author - Josphat Ngeno, MBA student, University of Kabianga

Second Author - Dr. Isaac K. Naibei, email inaibei@kabianga.ac.ke

Third Author - Dr. Penina C Langat, email: pchepkorir@kabianga.ac.ke

Correspondence Author - Dr. Isaac K. Naibei, email inaibei@kabianga.ac.ke 